\title{
Diversifying Coevolution between Crossbills and Conifers
}

\author{
Craig W. Benkman
}

Published online: 16 December 2009

(C) Springer Science+Business Media, LLC 2009

\begin{abstract}
Coevolution between granivorous crossbills (Loxia spp.) and conifers has been a prominent process in the diversification of crossbills. A striking example occurs in western North America where coevolution between crossbills and Rocky Mountain lodgepole pine (Pinus contorta latifolia) is ongoing in isolated ranges without the crossbill's dominant competitor for seeds, the red squirrel (Tamiasciurus hudsonicus). Preferential foraging by crossbills on lodgepole pine cones in the South Hills and Albion Mountains, two small mountain ranges in southern Idaho where red squirrels are absent, has led to the evolution of larger, thicker-scaled cones than in nearby ranges where red squirrels are present. This in turn has favored the evolution of larger-billed crossbills that have diverged from other crossbills in the region. However, such diversifying coevolution, resulting from geographic variation in the distribution of strongly interacting species, is vulnerable to species introductions. For example, the introduction of red squirrels caused the precipitous decline and perhaps extinction of the Newfoundland crossbill and perhaps a crossbill endemic to the Cypress Hills, Canada. In general, species introductions act to reduce the geographic variation in species interactions, which may be critical for the diversification of many taxa.
\end{abstract}

Keywords Crossbills · Conifers · Coevolution · Competition $\cdot$ Loxia $\cdot$ Tamiasciurus $\cdot$ Pinus contorta

C. W. Benkman $(\bowtie)$

Department of Zoology and Physiology, Program in Ecology,

University of Wyoming,

Laramie, WY, USA

e-mail: cbenkman@uwyo.edu

\section{Crossbill Diversity}

Twenty years ago, I began experiments to test a hypothesis for the ecological basis of Red Crossbill (Loxia curvirostra complex) diversity. I had been studying crossbills in eastern North America, and I had hypothesized that each species of crossbill was adapted for foraging on a different species of conifer that had certain characteristics that allowed for specialization (Benkman 1987a, b). Although crossbills are highly specialized seed predators (Fig. 1) that might be expected to coevolve with conifers, I had largely dismissed such coevolution. The prevailing view by those studying bird-plant interactions was that strong coevolutionary interactions were rare (e.g., Wheelwright and Orians 1982; Feinsinger 1983; see Thompson 1994). Moreover, the classic studies on seed-eating birds (e.g., Newton 1972; Schluter and Grant 1984; Pulliam 1985) indicated that considerable insight could be gained without considering whether plants were evolving defenses in response to selection exerted by birds (but see Pulliam and Brand 1975).

There are two groups of crossbills globally. One group is comprised of three distinct taxa with white wing bars. The Two-barred Crossbill (Loxia leucoptera bifasciata) in Eurasia, the White-winged Crossbill (Loxia leucoptera leucoptera) in the northern boreal forests of North America, and the Hispaniolan Crossbill (Loxia megaplaga) endemic to the pine forests atop two mountain ranges on Hispaniola. The other group, called Red Crossbills in the New World and Common Crossbills in the Old World, is much more diverse morphologically (Fig. 2) than the "wing-barred" crossbills and is widespread in the pine (Pinus spp.) and spruce (Picea spp.) forests of the Northern Hemisphere (Newton 1972). Most of the variation among Red/Common Crossbills is categorized into "call types" that are distinguished by differences in their vocalizations and in their bill 


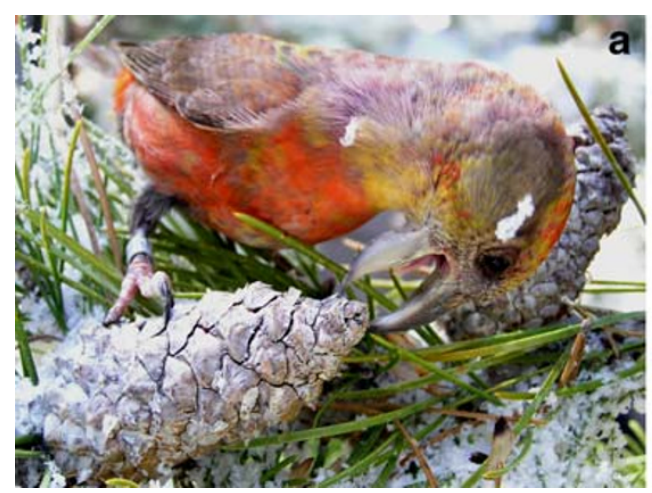

Fig. 1 South Hills crossbills foraging on lodgepole pine cones. Crossbills forage in a very stereotypic manner. a First, crossbills orient so that the vertical axis of the bill is aligned with the elongated surfaces of the cone scales, and then bite between adjacent and often hard, woody scales. Their crossed and decurved mandibles are key because they enable crossbills to exert and withstand strong forces at the mandible tips. Once the mandible tips reach between adjacent cone

and body sizes (Groth 1993; Benkman 1999; Summers et al. 2002, 2007; Edelaar et al. 2008); two call types in Eurasia, the Parrot Crossbill (Loxia pytyopsittacus) and Scottish Crossbill (Loxia scotica), are recognized as distinct species, and most other call types likely represent subspecies, species, or incipient species.

The hypothesis I tested was whether each of the four common call types in western North America was adapted to a different species of conifer whose seeds and cones are morphologically distinct from each other, and produce and hold seeds in their cones in a sufficiently reliable manner to allow specialization by crossbills. I predicted the "key conifers," which represent a small subset of all of the conifers in the crossbills' ranges, by examining the forestry literature that provided information on seed production and seed retention. My four hypothesized key conifers were western

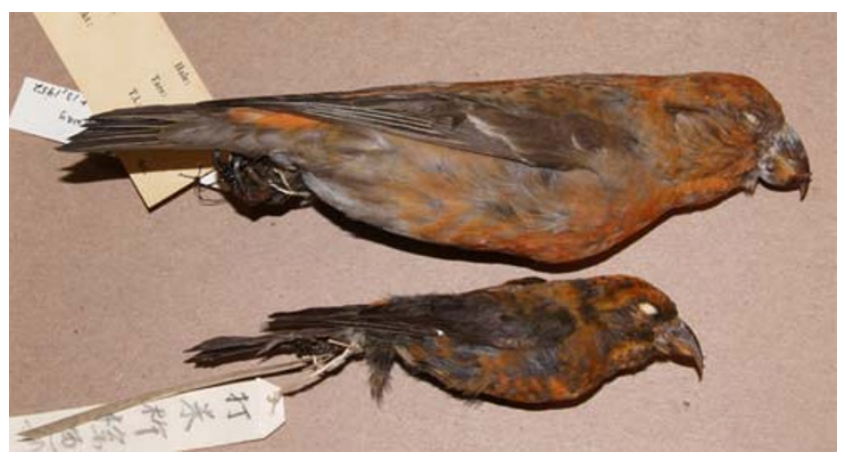

Fig. 2 Crossbills vary greatly in bill and body size. This shows the extremes in the variation in bill size, with the Parrot Crossbill (Loxia pytyopsittacus; top), the largest crossbill, and the Common Crossbill, Loxia curvirostra himalayensis (bottom; sensu Edelaar 2008), from the Himalayan Mountains the smallest. There are at least 12 distinct taxa of crossbills in the New World and probably up to 20 in the Old World (photo: Pim Edelaar)

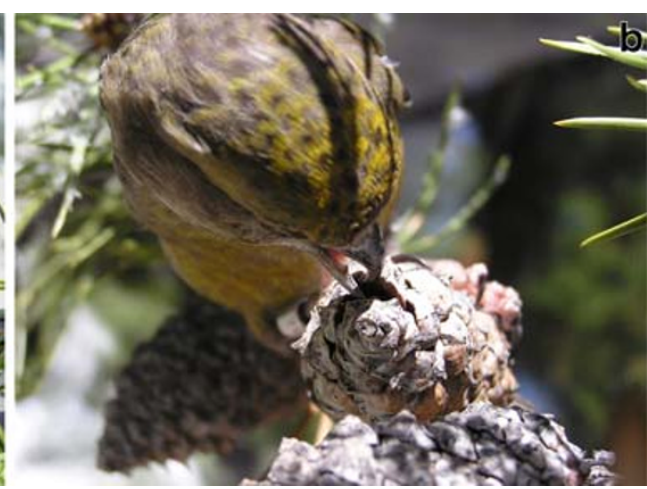

scales, the lower mandible is abducted laterally (b), spreading the scales apart, and exposing the seeds at their base. After using their tongue to reach into the gap between the scales to lift the seed out, crossbills secure the seed in a lateral groove in their palate. Their lower mandible cracks the seed coat, and the tongue and lower mandible remove and discard the seed coat before the kernel is swallowed (photos: the author)

hemlock (Tsuga heterophylla), Douglas-fir (Pseudotsuga menziesii), Rocky Mountain lodgepole pine (Pinus contorta latifolia), and Rocky Mountain ponderosa pine (Pinus ponderosa scopulorum). To test the hypothesis, I captured over 30 crossbills from the four call types and housed them in aviaries where I could conduct foraging experiments. Then I collected conifer cones and measured how fast crossbills could remove seeds from average-sized cones from each of the four conifers. I then solved for the optimal bill depth for foraging on each of the conifers (Fig. 3). If each call type was adapted for foraging on a particular conifer, then the average bill depth of a given call type should match the predicted optimum.

My experiments revealed that two of the call types matched the predicted optima, whereas two others were smaller than predicted (Benkman 1993). That the bill sizes of two of the call types were smaller than predicted did not cause me to reject the hypothesis, in part because I was able to estimate the optimal width of the groove in the crossbill's palate that is used to secure seeds while they are husked; groove width influences seed handling time, whereas bill depth is related to providing access to seeds in the cones (Fig. 3). In the case of the groove width, each call type matched or closely approximated the predicted optimum (Benkman 1993). Overall, the data were consistent with the hypothesis that each call type was adapted to a single species of conifer. Moreover, I could predict these conifers a priori based on their seed production and seed retention.

Interestingly, I initially hypothesized a fifth key conifer, Sitka spruce (Picea sitchensis), and thus a fifth call type (Benkman 1993). I had gathered foraging data on Sitka spruce cones, and I and my first graduate student, Bill Holimon, searched throughout much of the range of Sitka spruce (rainforests of the Pacific Northwest) for a fifth call 
a

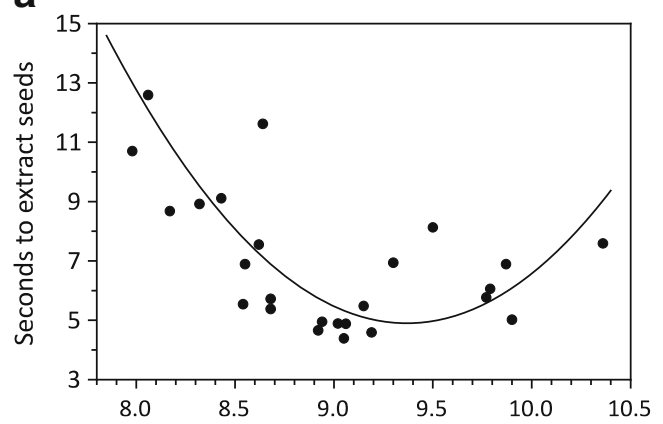

b

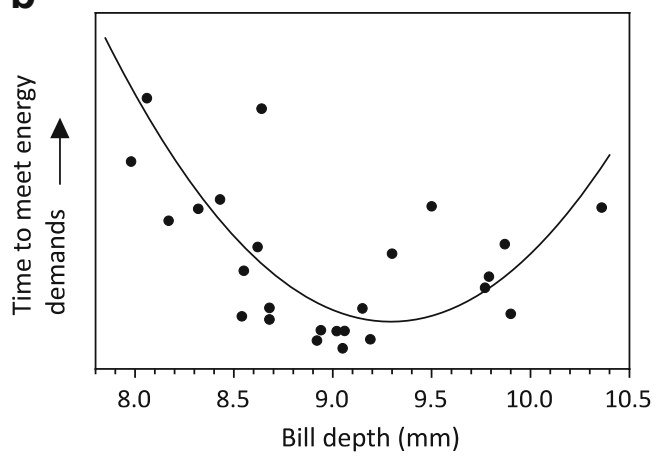

Fig. 3 An optimum is usually a function that is minimized or maximized given constraints. In the case of crossbills, the optimal bill depth is the bill depth that minimizes the time necessary to meet daily energy demands. Individuals that can meet their energy requirements more rapidly will have a competitive advantage when food is scarce, minimizing the risk of starvation and allowing them to do other things like find and court a mate. First, we need to consider the relationship between bill depth and time needed to remove seeds from the cones. An example is shown for 27 Red Crossbills timed foraging on Douglas-fir cones (Benkman 1993), where the bill depth minimizing the time to extract a seed is approximately 9.4 millimeters (Fig. 3a). In almost all cases, we have found a curvilinear relationship between time per seed and bill depth, with an intermediate bill depth requiring the least amount of time to extract a seed. However, the optimal bill depth is not simply the one that requires the least amount of time to extract a seed. Because body size increases allometrically with increases in bill depth in crossbills as in most seed-eating finches and sparrows (Benkman 1993; Benkman et al. 2001), daily energy requirements increase with increases in bill depth. Consequently, the optimal bill depth, which minimizes the product between time per seed and estimated daily energy requirements, is smaller than the time minimizing bill depth. The optimum is 9.3 millimeters in the example of crossbills foraging on Douglas-fir (Fig. 3b). The extent to which the optimum is shifted to a smaller size depends on the extent to which the decrease in energy requirements compensates for the increase in time per seed. In the example here, the optimal bill is only slightly $(0.1 \mathrm{~mm})$ smaller than the time minimizing bill depth

type. We did not find it. Over ten years later, however, an astute and diligent field ornithologist, Ken Irwin, living among Sitka spruce in northern California, discovered my hypothesized fifth call type (K. Irwin, unpublished manuscript). He has spent thousands of hours over the last eight years recording and observing this crossbill in the field. This crossbill not only spends nearly all of its time foraging on Sitka spruce, it also has a palate structure that matched what I had predicted over 15 years ago!

\section{Cone Variation, Red Squirrels, and Crossbills}

As I read the literature on conifers, I began to appreciate the extent of geographic variation in the structure of cones. If crossbills evolved to exploit different conifers, then what were the conifers and their cones evolving in response to? Geographic variation in cone structure was particularly interesting in Rocky Mountain lodgepole pine. Its cones were fairly uniform in size throughout the Rocky Mountains from the Yukon to Colorado, but much smaller than those in the isolated Cypress Hills (Wheeler and Guries 1982) nearly 300 kilometers east of the Rocky Mountains along the border of Alberta and Saskatchewan (Fig. 4a). This was especially intriguing because several years earlier, W. Earl Godfrey, the author of The Birds of Canada, had encouraged me to visit the Cypress Hills. In the late 1930s and early 1940s, Red Crossbills were common there, and they had large bills (Fig. 4a; Godfrey 1950). Moreover, red squirrels (Tamiasciurus hudsonicus), widespread throughout the Rocky Mountains, were absent from the Cypress Hills. The latter observation was significant, because in our conversation, I had told Godfrey of my ideas of how the absence of red squirrels from Newfoundland was critical to the evolution of a massive-billed crossbill on Newfoundland (Fig. 4b; Benkman 1989).

Nine thousand years ago, black spruce (Picea mariana) and presumably crossbills colonized Newfoundland after the glaciers retreated. However, red squirrels and a number of other land mammals did not colonize Newfoundland. In the absence of red squirrels, which are strong competitors for conifer seeds and also strong selective agents on cone structure (Smith 1970), I had argued that crossbills had evolved to exploit cones that had lost their defenses directed at red squirrels (Benkman 1989). Chris Smith had provided compelling evidence that red squirrels coevolved with Rocky Mountain lodgepole pine and that many of its cone traits were related to selection exerted by red squirrels (Smith 1970). Although I suspected that selection exerted on cones by red squirrels had contributed greatly to the evolution of other conifers including black spruce, I still had no evidence that crossbills have an evolutionary effect on conifer cones. I needed to visit the Cypress Hills.

Unfortunately, red squirrels had been introduced to the Cypress Hills in 1950, after Godfrey's visits (Benkman 1999). Red squirrels were also introduced to Newfoundland in 1963. This latter introduction was to increase the prey base of the over-trapped Newfoundland pine marten (Martes Americana atrata) that numbered in the low hundreds. Although red squirrels spread rapidly across 
a

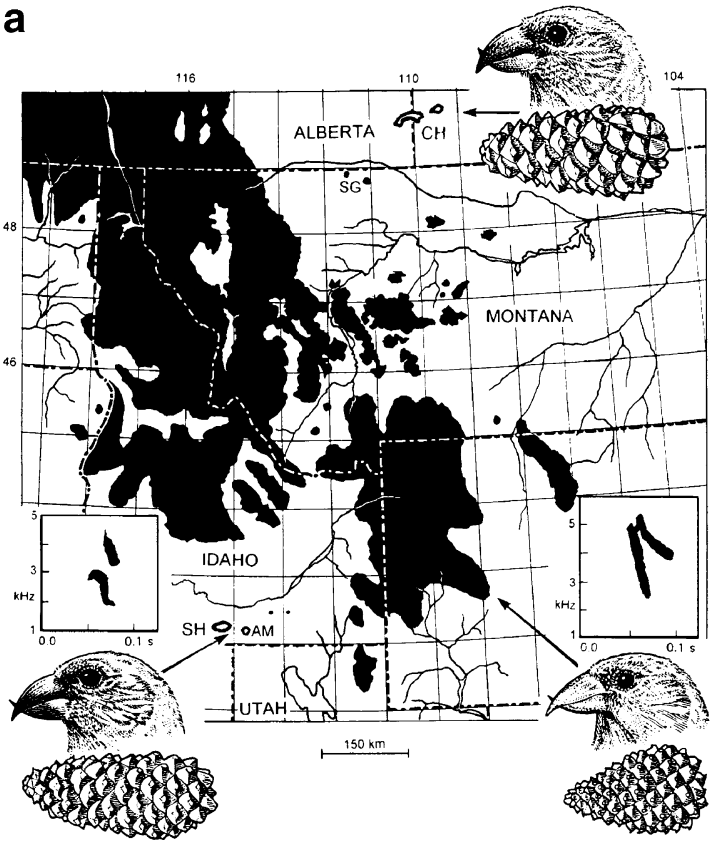

Fig. 4 Two examples of crossbill and conifer evolution and coevolution. a The distribution of Rocky Mountain lodgepole pine (black) and crossbills and cones in the Rocky Mountains (lower right), Cypress Hills (upper right), and South Hills and Albion Mountains (lower left). Representative sonograms of flight calls are shown for the South Hills crossbill (lower left) and the Rocky Mountain lodgepole pine crossbill (lower right; from Benkman 1999). Red squirrels (Tamiasciurus hudsonicus) are found throughout the range of Rocky Mountain lodgepole pine, except in some isolated mountains, including the Cypress Hills (CH), Sweetgrass Hills (SG), South Hills (SH), and Albion Mountains (AM). Red squirrels were absent from

Newfoundland and occur in much higher densities than in comparable forests on the mainland, pine martens have not recovered. Red squirrels have flourished in Newfoundland because in the 9,000 years that black spruce evolved in the absence of red squirrels, the spruce have lost a considerable amount of defense directed at red squirrels. When red squirrels forage on conifer cones, they start at the base and bite off successive scales to reach the underlying seeds that tend to be concentrated at the distal end of the cone. Red squirrels avoid trees whose cones have few seeds and few seeds relative to the mass of cone they need to bite through to reach the seeds. In the absence of red squirrels, the number of seeds per cone increased, and the ratio of cone mass to seed mass in black spruce cones decreased by a third on Newfoundland relative to nearby areas in Quebec where red squirrels are present (Parchman and Benkman 2002). These cone traits appear to be highly heritable, and differences in cone traits among trees appear to represent mainly genetic rather than environmental differences. Those trees that produced less cone mass per seed were presumably at an advantage because they were able to shift their allocation of resources to additional seed production. These black spruce, however, are poorly defended against

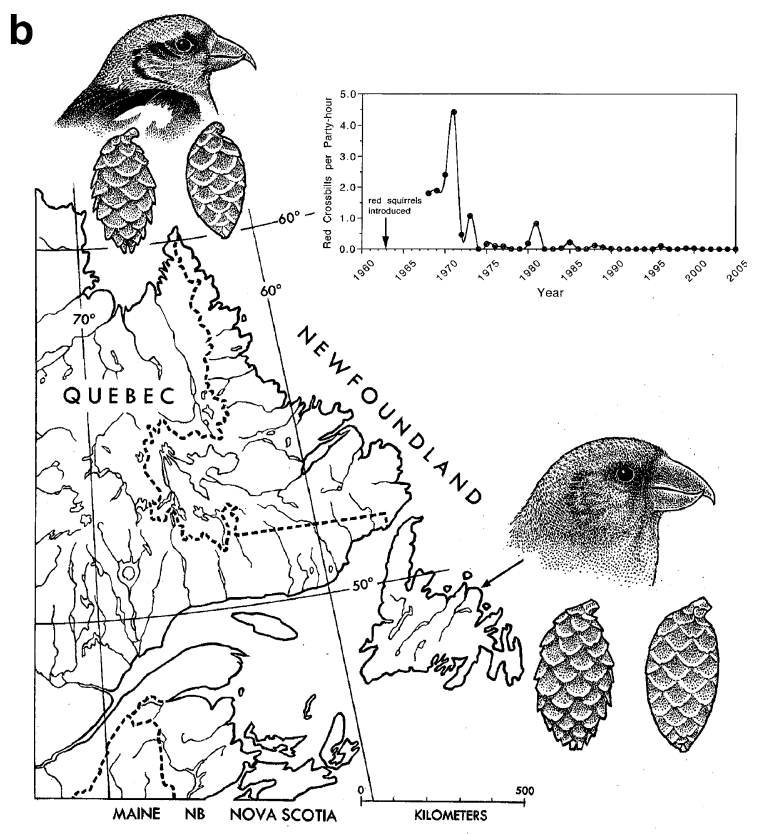

the Cypress Hills until they were introduced in 1950. b A whitewinged crossbill (Loxia leucoptera leucoptera; upper left) and a Newfoundland crossbill (Loxia curvirostra percna; lower right), and representative partially closed and closed black spruce cones from the mainland (upper left) and Newfoundland (lower right; from Parchman and Benkman 2002). Red squirrels occur throughout the spruce forests of the mainland and were introduced onto Newfoundland in 1963. The inset in the upper right shows the number of red crossbills per partyhour observed during annual Christmas Bird Counts in Terra Nova National Park, Newfoundland from 1968 to 2005. A "party-hour" is one hour of observation by one group of observers

the introduced red squirrels, which now harvest a vast majority of the cones during autumn soon after the seeds mature (West 1989). This extensive removal of cones by red squirrels may account for the rapid decline of the Newfoundland crossbills beginning about ten years after red squirrels were introduced (Fig. 4b; Benkman 1989; Parchman and Benkman 2002).

The Cypress Hills is orders of magnitude smaller than Newfoundland, and red squirrels were introduced over ten years earlier to the Cypress Hills than to Newfoundland. Thus, if the formerly common Newfoundland crossbill is extinct or at best exceedingly rare (Fig. 4b), I did not hold out much hope for the Cypress Hills crossbill (Fig. 4a). Although I have not conducted extensive surveys in the Cypress Hills, crossbills are uncommon there (Siepielski and Benkman 2005), and we have not detected a distinctive call type. The abundant red squirrels in the Cypress Hills, however, provided an excellent opportunity to measure the selection they exert on lodgepole pine cone morphology.

One fall, while quantifying cone preferences to estimate selection exerted by red squirrels in the Cypress Hills, I came to a vantage point where I could see the similarly isolated and smaller group of mountains, the Sweetgrass Hills, across the 
border in Montana (Fig. 4a). After finishing our work in the Cypress Hills, we drove to the Sweetgrass Hills. There are only about five square kilometers of lodgepole pine in the Sweetgrass Hills, and there were no red squirrels, and none had been introduced. Cones in both the Cypress and Sweetgrass hills showed evidence of losing defenses directed at red squirrels (58\% and 36\% decreases, respectively, in the ratios of cone mass to seed mass relative to cones from the Rocky Mountains), having evolved in their absence for probably close to 12,000 years (Benkman 1999). However, the cones in the Sweetgrass Hills, where crossbills were uncommon (Siepielski and Benkman 2005), were smaller, and the scales at the distal end of the cone where crossbills mostly forage (Fig. 1) were thinner than in the Cypress Hills. This variation in scale thickness and the thick distal scales in the Cypress Hills in particular were inconsistent with cone evolution simply in response to selection and relaxation of selection by red squirrels. The obvious explanation was that increased thickness of the distal scales was an evolutionary response to selection exerted by crossbills. Crossbills should avoid cones with thicker distal scales because they would impede crossbills from spreading apart the scales to reach the seeds at the base (Fig. 1b). However, in the absence of a Cypress Hills crossbill to study, I sought additional isolated ranges of lodgepole pine to determine if the differences I had found between the Sweetgrass Hills and the larger-sized Cypress Hills were repeated.

\section{Crossbill-Conifer Coevolution}

Examining range maps, I located several small isolated ranges west of the Rocky Mountains in southern Idaho where red squirrels were apparently absent and lodgepole pine appeared to occupy about as much area as in the Sweetgrass Hills. I visited the two most isolated ranges, the Albion Mountains and South Hills (Fig. 4a), to collect cones on my way to an ornithology meeting. It turned out the forest maps were inaccurate. The lodgepole pine forests are if anything slightly more extensive than in the Cypress Hills, and the cones were like those in the Cypress Hills (Fig. 4a). Moreover, crossbills were very common, and they even sounded like they might be a different call type. Here was the opportunity to study a crossbill that was potentially coevolving with its food plant. I went to the meeting telling colleagues that I had found a new crossbill.

The next year, I returned to the South Hills to capture crossbills. The crossbills occurred in densities that were about 20 times higher than in lodgepole pine forests in the Rocky Mountains, presumably because their competitor, the red squirrel, was absent (Benkman 1999; Siepielski and Benkman 2005). South Hills Crossbills were larger than other crossbills in western North America, and they had a distinctive call (Fig. 4a). The question remained, were these differences the result of a coevolutionary arms race between crossbills and lodgepole pine in the South Hills? To test this hypothesis, I needed to quantify the forms of selection both exerted and experienced by crossbills. If the selection exerted by crossbills could account for the differences in cone traits between the South Hills and the Rocky Mountains, beyond that resulting from differences in the presence and absence of selection by red squirrels, then this would suggest that crossbills are altering the course of cone evolution. Furthermore, if these differences in cone traits were favoring a larger bill, then these results would support the hypothesis of coevolution.

We have found that the one cone trait that consistently deters crossbills from foraging in both the field and in aviaries is thicker cone scales. This is true for several pines in the Rocky Mountains and in the Mediterranean (Benkman et al. in press). A particularly striking example concerns mountain pine (Pinus uncinata) in the Pyrenees (Fig. 5; Mezquida and Benkman in press). Crossbills avoid foraging on trees whose cones have thick scales, which results in selection favoring the evolution of thicker scales. In the case of lodgepole pine, crossbills forage mostly at the distal end of the cone (Fig. 1b) where most of the seeds are located (Smith 1970), and thus cones with thicker distal scales are avoided (Benkman et al. 2001, 2003). This preference, and thus differential seed predation and selection, presumably accounts for the relatively thick distal scales in the South and Cypress hills (Fig. 4a).

Our data also indicate that an increase in scale thickness favors larger-billed crossbills, resulting in the evolution of the large-billed crossbills in the South Hills (Benkman et al. 2001, 2003). However, as in my aviary experiments from years before (Benkman 1993), we found that the South Hills crossbill was smaller than that predicted if it was adapted for foraging on the average-sized cone (Benkman et al. 2001, 2003). Although at first I was puzzled by South Hills crossbills having bills smaller than what we initially predicted, in retrospect, this makes sense because crossbills do not forage on average-sized cones. South Hills crossbills preferentially forage on cones that are smaller than average (J. Smith et al., unpublished data). Once we account for this behavior, which is what drives the coevolutionary process in the first place, South Hills crossbills match well what would be predicted based on the cone sizes they mostly forage on (C. W. Benkman, unpublished data).

Let me summarize what we have learned (Fig. 4a). Red squirrels are common throughout most of the range of Rocky Mountain lodgepole pine. They are superior competitors for seeds in the cones and, as a result, crossbills are uncommon in these forests. Selection exerted by red squirrels drives the evolution of cone structure, and crossbills adapt to the average cone. In several isolated mountain ranges east and 


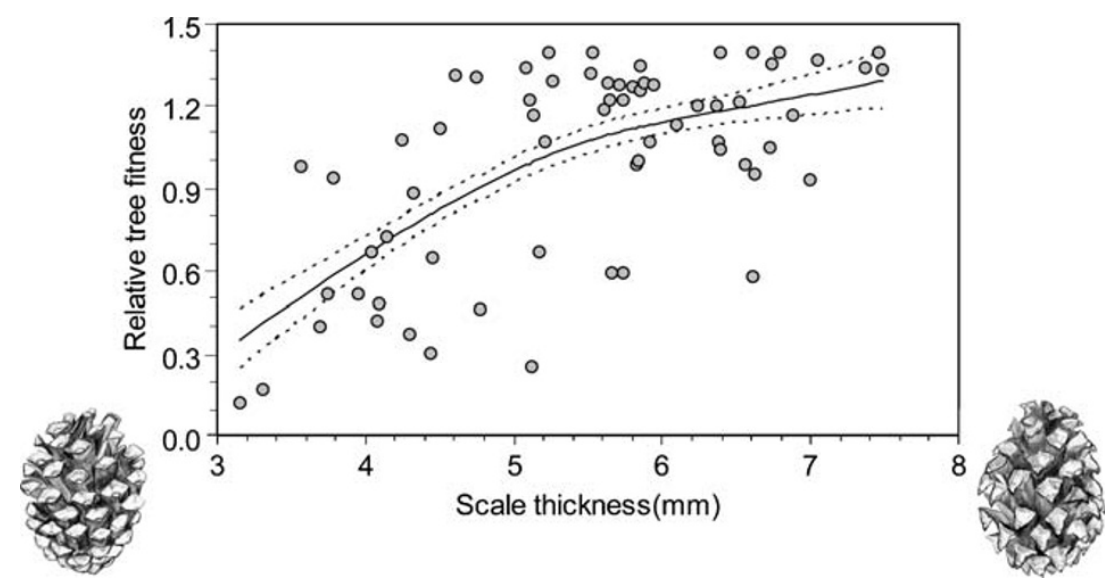

Fig. 5 The relationship between relative tree fitness because of seed predation by crossbills and scale thickness in the western Pyrenees $(n=65$ trees; from Mezquida and Benkman in press). The solid curve represents a cubic spline, and the dashed curves represent \pm one SE

west of the Rocky Mountains, red squirrels are (were for the Cypress Hills) absent. Here, the pines had lost their defenses directed at red squirrels and, in the absence of red squirrels, crossbills are up to 20 times more abundant than in the Rocky Mountains. Crossbills are now the primary seed predator and exert selection on cone structure favoring the evolution of increased defenses directed at crossbills (i.e., thicker distal scales). This in turn favors the evolution of crossbills with larger bills and over time has favored a continuing escalation in the defenses of pines and the counter-offenses in crossbills, typifying a coevolutionary arms race. Remarkably, we find the pattern of coevolution in the South Hills replicated east of the Rocky Mountains in the Cypress Hills (Fig. 4a). Furthermore, these patterns of cone evolution are strikingly replicated in black spruce in Newfoundland (Fig. 4), and this has all occurred within the last 12,000 years or even less (Benkman et al. 2001; Parchman and Benkman 2002). Now, the South Hills crossbill only rarely interbreeds with other call types that move into the South Hills yearly (Smith and Benkman 2007) and can be considered to represent a distinct species (Loxia sinesciurus or "the crossbill without tree squirrels"; Benkman et al. 2009). Coevolution is clearly a dynamic and powerful force that causes crossbill populations to diverge rapidly and even speciate.

One question remains. How widespread is coevolution in the adaptive radiation of crossbills? We have found similar evidence for evolution in response to selection exerted by crossbills in most of the conifers that crossbills are specialized upon (Benkman et al. in press). This also helps to explain the pattern described earlier for some crossbills matching the optimum bill depth for foraging on their respective key conifers and some having bills smaller than the optimum for foraging on average cones; none have larger bills. As we have discovered repeatedly, crossbills usually forage on smaller based on 50 bootstrap replicates. The drawings of the two cones represent the variation in scale thickness from thinner scales on the left to thicker scales on the right

than average-sized cones of their respective key conifers (Benkman et al. 2003; Parchman and Benkman 2008; Benkman and Parchman 2009; Mezquida and Benkman in press), presumably because this allows them to have higher feeding intake rates (Benkman 1999). Those crossbills, for which we have evidence of their either exerting selection on their key conifers, or evolution of increased crossbill defenses in their key conifers, are the crossbills having smaller than "optimal" bills (the Douglas-fir [call type 4], ponderosa pine [call type 2], and South Hills [call type 9] crossbills; Benkman et al. in press). In contrast, those crossbills for which we have no evidence of their exerting selection on cone structure match the predicted optima (lodgepole pine [call type 5] and western hemlock [call type 3] crossbills - although the hemlock crossbill appears not to preferentially forage on smaller cones, it apparently exerts selection on seed coat structure; Benkman et al. in press).

In conclusion, coevolution is an important process in the diversification of crossbills, and examining how this process manifests itself has helped us unravel the patterns of diversification in crossbills. In addition, our studies reveal that variation in the distribution of co-occurring species has caused geographic variation in coevolution (geographic mosaic of coevolution; see Thompson in this volume). Other investigators have found that geographic variation in the occurrence and outcome of coevolution arises because of variation in the distribution of co-occurring species, including competitors (Craig et al. 2007), alternative hosts (Zangerl and Berenbaum 2003), and co-pollinators (Thompson and Fernandez 2006; see Thompson in this volume). In our studies, discontinuities in the distribution of other species or variation in the species composition of communities (i.e., community context) arise because of biogeographical factors differentially limiting dispersal (large treeless expanses preventing red squirrels but not birds from colonizing 
forests: e.g., Benkman et al. 2001; Siepielski and Benkman 2007). In other studies, geographic variation arises because the distributions of some but not all interacting species span two adjacent biomes (e.g., prairie and forest: Craig et al. 2007). If variation in the species composition of communities (i.e., community context) is what often generates geographic variation, then we need to minimize the introduction of species, even species from nearby areas. Introductions of species, especially strongly interacting species like red squirrels, not only cause extinctions but also act to homogenize interactions across the landscape (Benkman et al. 2008). Without this geographic variation, speciation and diversification will be impeded (Mayr 1963; Coyne and Orr 2004), and future opportunities for diversification will be lost.

Acknowledgments The National Geographic Society, NSERC, and especially the National Science Foundation (most recently DEB-0344503 and DEB-0455705) have funded most of my research on crossbills. I thank the editors, R. Medel and J. N. Thompson, for inviting me to write this paper, and J. Hart, T. Parchman, A. Siepielski, L. Throop, an anonymous reviewer, and the editors for commenting on the manuscript.

\section{References}

Benkman CW. Food profitability and the foraging ecology of crossbills. Ecol Monogr. 1987a;57:251-67.

Benkman CW. Crossbill foraging behavior, bill structure, and patterns of food profitability. Wilson Bull. 1987b;99:351-68.

Benkman CW. On the evolution and ecology of island populations of crossbills. Evolution. 1989;43:1324-30.

Benkman CW. Adaptation to single resources and the evolution of crossbill (Loxia) diversity. Ecol Monogr. 1993;63:305-25.

Benkman CW. The selection mosaic and diversifying coevolution between crossbills and lodgepole pine. Am Nat. 1999;153:S75-91.

Benkman CW, Parchman TL. Coevolution between crossbills and black pine: the importance of competitors, forest area, and resource stability. J Evol Biol. 2009;22:942-53.

Benkman CW, Holimon WC, Smith JW. The influence of a competitor on the geographic mosaic of coevolution between crossbills and lodgepole pine. Evolution. 2001;55:282-94.

Benkman CW, Parchman TL, Favis A, Siepielski AM. Reciprocal selection causes a coevolutionary arms race between crossbills and lodgepole pine. Am Nat. 2003;162:182-94.

Benkman CW, Siepielski AM, Parchman TL. The local introduction of strongly interacting species and the loss of geographic variation in species and species interactions. Mol Ecol. 2008; 17:395-404.

Benkman CW, Smith JW, Keenan PC, Parchman TL, Santisteban L. A new species of red crossbill (Fringillidae: Loxia) from Idaho. Condor. 2009;111:169-76.

Benkman CW, Parchman TL, Mezquida ET (2010) Patterns of coevolution in the adaptive radiation of crossbills. The Year in Evolutionary Biology, Vol 3, in press.

Coyne JA, Orr HA. Speciation. Sunderland: Sinauer Associates; 2004.

Craig TP, Itami JK, Horner JD. Geographic variation in the evolution and coevolution of a tritrophic interaction. Evolution. 2007;61:1137-52.

Edelaar P. Rediscovery of a second kind of crossbill for the Himalayan region, and the hypothesis that ecological opportunity drives crossbill diversification. Ibis. 2008;150:405-8.
Edelaar P, van Eerde K, Terpstra K. Is the nominate subspecies of the common crossbill Loxia c. curvirostra polytypic? II. Differentiation among vocal types in functional traits. J Avian Biol. 2008;39:10815.

Feinsinger P. Coevolution and pollination. In: Futuyma DJ, Slatkin M, editors. Coevolution. Sunderland: Sinauer Associates; 1983. p. 282-310.

Godfrey WE. Birds of the Cypress Hills and Flotten Lakes regions, Saskatchewan. Department of Resources and Development Bull no. 120. Ottawa: National Museum of Canada; 1950.

Groth JG. Evolutionary differentiation in morphology, vocalizations, and allozymes among nomadic sibling species in the North American Red Crossbill (Loxia curvirostra) complex. Univ Calif Publ Zool. 1993;127:1-143.

Mayr E. Animal species and evolution. Cambridge: Harvard University Press; 1963.

Mezquida ET, Benkman CW (2010) Habitat area and structure affect the impact of seed predators and the potential for coevolutionary arms races. Ecology 91, in press.

Newton I. Finches. London: Collins; 1972.

Parchman TL, Benkman CW. Diversifying coevolution between crossbills and black spruce on Newfoundland. Evolution. 2002;56:1663-72.

Parchman TL, Benkman CW. The geographic selection mosaic for ponderosa pine and crossbills: a tale of two squirrels. Evolution. 2008;62:348-60.

Pulliam HR. Foraging efficiency, resource partitioning, and the coexistence of sparrow species. Ecology. 1985;66:1829-36.

Pulliam HR, Brand MR. The production and utilization of seeds in plains grassland of southeastern Arizona. Ecology. 1975;56:1158-66.

Schluter D, Grant PR. Determinants of morphological patterns in communities of Darwin's finches. Am Nat. 1984;123:175-96.

Siepielski AM, Benkman CW. A role for habitat area in the geographic mosaic of coevolution between red crossbills and lodgepole pine. J Evol Biol. 2005;18:1042-9.

Siepielski AM, Benkman CW. Convergent patterns in the selection mosaic for two North American bird-dispersed pines. Ecol Monogr. 2007;77:203-20.

Smith CC. The coevolution of pine squirrels (Tamiasciurus) and conifers. Ecol Monogr. 1970;40:349-71.

Smith JW, Benkman CW. A coevolutionary arms race causes ecological speciation in crossbills. Am Nat. 2007;169:455-65.

Summers RW, Jardine DC, Marquiss M, Rae R. The distribution and habitats of crossbills Loxia spp. in Britain, with special reference to the Scottish Crossbill Loxia scotica. Ibis. 2002;144:393410.

Summers RW, Dawson RJG, Phillips RE. Assortative mating and patterns of inheritance indicate that the three crossbill taxa in Scotland are species. J Avian Biol. 2007;38:153-62.

Thompson JN. The coevolutionary process. Chicago: University of Chicago Press; 1994.

Thompson JN, Fernandez CC. Temporal dynamics of antagonism and mutualism in a geographically variable plant-insect interaction. Ecology. 2006;87:103-12.

West RJ. Cone depredations by the red squirrel in black spruce stands in Newfoundland: implications for commercial cone collection. Can J For Res. 1989;19:1207-10.

Wheeler NC, Guries RP. Population structure, genic diversity, and morphological variation in Pinus contorta Dougl. Can J For Res. 1982;12:595-606.

Wheelwright NT, Orians GH. Seed dispersal by animals: contrasts with pollen dispersal, problems of terminology, and constraints on coevolution. Am Nat. 1982;119:402-13.

Zangerl AR, Berenbaum MR. Phenotype matching in wild parsnip and parsnip webworms: causes and consequences. Evolution. 2003;57:806-15. 